chlorine. During the War, instructions were given to all water undertakings in Great Britain to chlorinate the water under their care. Lord Amulree said that this was done as a protection against sabotage by enemy agents, and has led to the erroneous idea that so long as a certain amount of chlorine is put into the water, the water is automatically safe for consumption and that very little or no care need be paid to other forms of treatment or to care of the source. This easy and fatal attitude of mind is one which it is going to be very difficult to eradicate. The fact that chlorination should be under skilled and intelligent supervision, with laboratory control, makes the process difficult to provide for in small rural supplies; hence it becomes more and more important for them to acquire a source free from pollution and to take steps to keep it so.

Some waters are corrosive to lead, and require treatment to protect the consumers from lead poisoning. This is due to the acidity of the water, and is usually corrected by the addition of lime.

Much discussion has taken place during the last hundred years on the relative merits of hard and soft water, and it has been contended that the use of a soft water not only results in a saving of soap but also that food cooked in soft water is more wholesome and more palatable, and that there is a saving in the wear and tear of garments washed in soft water. There are two processes used for water softening. One is based on the process evolved by Prof. Clark, and consists of adding lime to the water and precipitating the calcium bicarbonate as calcium carbonate. The other is called the base-exchange or zeolite method. When hard water is passed through a bed of natural zeolite or artificial base-exchange material, the sodium ions of the zeolite pass into the water and are replaced by the calcium and magnesium ions of the water which combine with the zeolite. By this means a completely softened water is obtained, and when the water issuing from the apparatus is no longer soft the material is regenerated by passing sodium chloride through it and thus reversing the exchange. In particular cases treatment has to be given for the removal of iron, which imparts an unpleasant taste to the water and stains elothing in the laundry. The treatment consists of aeration and sedimentation or filtration. Algæ which interfere with filtration and sometimes give rise to obnoxious tastes in the water may be controlled by treatment with copper sulphate or by coagulation.

Lord Amulree pointed out that the War has brought many new difficulties to water undertakings. In the first place, there was the establishment of camps and training grounds for troops, which led to the possibility of contamination of gathering grounds as well as the necessity for providing largely increased supplies of water. A further danger was the possibility of sabotage or the dropping of chemical or bacterial poisons into reservoirs from enemy aircraft. So far as is known, no attempt to poison water supplies has been made by the enemy.

'The bombing of towns brought another danger, when water mains were broken in the same street as sewers. Owing to the great care that has been taken to isolate all sections of damaged mains and to sterilize them with chlorine after they have been repaired and before being put back to service, this danger has been successfully overcome.

DenisoN B. ByLes.

\section{PROSPECTS OF CIVIL AVIATION}

N November 4 the Royal Aeronautical Society held at the Institution of Mechanical Engineers a discussion on civil aviation, and I agreed to preside. The time was appropriate in that a British Empire technical conference on the subject had just been held at Ottawa and one was going on on international aviation at Chicago. True, there is this difference in that, whereas agreement was required at the conferences, disagreement was required at the Royal Aeronautical Society's meeting in order to get real discussion.

The conduct of a meeting of this kind is always difficult: technicians are retiring, shy people as a rule, with the result that if you wait for someone to get up, it looks as if the meeting is slow, while if you call on people it appears to be pre-arranged and not spontaneous.

The canvas is very large that contains the picture of civil aviation, and it was certainly not our province to discuss any portion of it that brought in political prejudices or differences. How training or the economics of civil air transport comes within the ambit of a purely scientific society is not very clear, except on the basis that there is no one else to deal with it. I do not know whether a Saturday is a good day for such a gathering, starting at 10.30 a.m. and continuing until 6 p.m., but such was the demand to attend that tickets for admission were hard to come by and the place was full.

Brigadier-General Critchley, the director-general of British Overseas Airways Corporation, opened the discussion, speaking on training for civil purposes. He showed that much thought has been given to the subject. A pilot's career starts at twenty, for example; he must go anywhere until he is thirty. five, after which he can choose his route by virtue of his domestic ties until he is forty-five, when he comes off flying; but meanwhile he is to have training in administrative work, to see if he would be suitable for further employment in that line. It was interesting to note that one aircraft should average 3,000 hours a year and requires three crews to fly it. Accidents have been shown throughout the world to be at least 85 per cent pilot's errors.

Training for the R.A.F. and civil flying were said to be very different, a point disputed by Air Marshal Longmore as to engineers aboard. Altogether, chosen instrument or not, the personnel training of British Overseas Airways looked good, and General Critchley certainly impressed the meeting.

Major Thornton, a shipping director of Holts, an amateur flyer, a member of the Air Registration Board and a most treasured member of my Committee on Civil Aviation, dealt with the economics of flying, and startled everyone by saying he was surprised at being asked to speak on such a theme as the two subjects had never met! Coming from one who has dealt all his life with the running of tramp ships, his was a most enjoyable and instructive talk. $\mathrm{He}_{\theta}$ discuissed frequency versus big machines, and showed a preference for frequency; but no one pointed out that the tiresome route London-New York non-stop compels at present a big machine on technical grounds. Major Thornton poured scorn, very rightly, on the aeroplane as a rival to ordinary freight carriers, but said it would create a new type of freight which is only of value if carried from place to place quickly.

Dr. Roxbee Cox pleaded for non-commercial routes 
to be run to open up areas, an important side of this subject.

Sir Frederick Handley Page wanted to know if the jet would jump us from the speed of 200 m.p.h. to 300 m.p.h. without much difference in economy.

Mr. Peter Masefield made the curious point that 100 per cent load factor is uneconomical in view of the waste of money consumed in the organization necessary to reserve places, allot priorities, etc.; 60 per cent load factor, arrive and take your seat, would seem better! This particular subject is very large and requires and deserves much more attention than it got during a morning's discussion.

In the afternoon, Mr. Roy Chadwick, chief designer to A. V. Roe's of Manchester, who was responsible for the most remarkable of all bombers-the Lancaster -started the proceedings, but with war-time caution would only talk of conventional aircraft, whereas everyone, I believe, wanted to be done with them and dream of the next step. Along the lines of the conventional, however, he wanted a general purpose machine of about 100,000-150,000 lb. weight, 1,000 miles range, carrying thirty people, to cruise if needed at 300 m.p.h.

The great Hives followed him, the soul of Rolls Royce, and what a lot we owe to him for his own genius and the teams under him, unequalled in the world. . He started by making the interesting point that whereas a locomotive does 100,000 miles between overhauls, an aero engine, although universally cursed, does 150,000 miles between overhauls. $\mathrm{He}$ would not admit that design for war engines is different from that of engines for civil use, except in minor points. He stressed the importance for maintenance of the whole power plant being interchangeable. Petter did not like this, but I do not think Hives meant that all power plants should be the same, as that would restrict design; but that in many machines you should be able to take out and replace the whole plant. Air Commodore Banks agreed that peace and war engines were similar.

Here I must state candidly that although both Chadwick's and Hives' contributions were most valuable and interesting, the fact that we are at war and unable for security reasons to speak of so much that is interesting, made the whole discussion rather flat; but that was not their fault.

Mr. Ogston pointed out that the cost of fuel for a year equalled the cost of the aeroplane. Hives countered with the Queen Mary, and worked it out in his head at more than half the cost a year !

Mr. C. G. Grey, comparing the difference in form of the Fortress and Liberator, which have identical performances, drew the startling deduction that both must be wrong and that aeronautics was not a science at all !

Mr. F. F. Crocombe put the size of a tail-less machine at $260,000 \mathrm{lb}$. before showing advantage over the conventional type. Wings, I suppose, get deep enough then to carry useful load and human beings. No trouble in landing gear in big machines was anticipated, the flexing of large spars not being mentioned.

Dr. Roxbee Cox described the jet engine well and pleaded for speed so as to get his engines to give more real horse-power. He was surprisingly optimistic on fuel consumption relative to ground covered, and I hope he is right.

Hives, in replying, admitted that Rolls Royce are in the jet business. He did not say whole-heartedly, but if this was not known before, some engine manufacturers will feel a cold douche down their backs.

Mr. W. P. Hildred, director general of civil aviation and another member of my Committee, spoke well and with great knowledge on route facilities. $\mathrm{He}_{\boldsymbol{\theta}}$ put some difficult questions to us, such as what regularity of service is wanted ; is ground organization spoiling pilots, what radio aids are really needed, etc., and even asked if aircraft should be self. navigating. It was noble of him to come along, bombarded and harassed as he was by the representatives at the conference in Chicago, asking for loads of information from his broad shoulders.

After tea-for the meeting went on until 6 p.m.Mr. J. P. Jeffcock made the point that aircraft operators should compel the radio world to give them what they want rather than to take ready-made goods. After the War, radio aids should be on the ground, not all in the aircraft as war demands.

Sir Roy Fedden, president of the Royal Aeronautical Society, to whom the Society owes so much, was the last speaker, and told us what we had all realized, namely, that in spite of the hours spent, we had only touched the surface of many problems; and that once the conferences in the United States are finished, we are to have another day of discussion. The Society's secretary, Captain Pritchard, was expected to gasp, but in fact he suggested it, so in the New Year we shall be at it again.

Brabazon OF TARA.

\section{NEWS and VIEWS}

\section{Teaching and Research in Industrial Health}

THE announcement by the Nuffield Trust of grants totalling $£ 150,000$ for teaching and research in industrial health is a reminder of the importance of this hitherto neglected aspect of the nation's wellbeing. In the early eighteenth century, Ramazzini, inthis famous "Diseases of Tradesmen", emphasized the risks to health associated with certain occupations; yet it was not until the War of 1914-18 that oficial interest, apart from a few industrial hazards, was aroused in industrial health. In 1915 it was realized in Britain that munition workers suffering from ill-health were a serious liability to the safety of the country, since their absence affected production. The Health of Munition Workers' Com- mittee, formed in 1915, found that few organizations kept health records, and that the need for preserving the health of those who work with hands or brain was but feebly recognized. Since 1918 progress has been made, and the recognition of the need for industrial medical officers, industrial nurses, welfare workers and labour managers has become more widely spread. It is, however, chiefly the firms with the best conditions who do the most to safeguard the health of their employees in all ways. There are numerous organizations still existing where health is nobody's concern. - There are two aspects to be considered : (a) the need for systematic research into the actual incidence of sickness absence from various causes; (b) the means of expressing the results of this research in such a way that it can be applied easily. Before 